\title{
PENGARUH PEMBERIAN KORSET LUMBAL DAN BACK EXERCISE PADA PASIEN LOW BACK PAIN NON SPECIFIC DI KLINIK FISIOTERAPI FITASOMA SURAKARTA TAHUN 2014
}

\author{
Scholastica Theresia Susilowati, Heru Purbo Kuntono \\ Kementerian Kesehatan Politeknik Kesehatan Surakarta Jurusan Fisioterapi
}

\begin{abstract}
Pain Low Back Pain, Lumbar Corset, Back Exercise. Pain is the major complaint that the majority of cases seen in patients with low back pain. This situation has been very disturbing in routine daily activities. The highest incidence of pain is found, the result of abnormal mechanics of motion, or postural abnormalities that lasts for a long time. There are several tools that can be used to reduce pain in low back pain. One means is the use of a corset for the lumbar region (lumbar corset) and perform a back exercise such as muscle strengthening exercises lower back. The study was conducted on patients consisting of mothers of households with children under five with the case, in Karanganyar Fitasoma Physiotherapy Clinic Surakarta, in the period between January to December 2014. This study is a quasi experimental study. The data collection is done by observation, interview, physical examination, and documentation. 40 respondents sought through observation, to be subjects for further research. Based on this research, it was found that the decrease of pain in the first two weeks, either in a group or a group giving a lumbar corset back giving exercise. In addition, also found functional improvements in lumbar corset administration group after the first week, and the provision of back exercise group after the second week.
\end{abstract}

Keywords: Pain Low Back Pain, Lumbar Corset, Back Exercise

Abstrak: Nyeri Low Back Pain, Korset Lumbal, Back Exercise. Rasa nyeri adalah keluhan utama yang mayoritas didapatkan pada pasien dengan kasus low back pain. Keadaan ini dirasakan sangat mengganggu dalam aktivitas rutin setiap hari. Insiden nyeri terbanyak yang ditemukan, merupakan akibat kelainan mekanika gerak, atau kelainan postural yang berlangsung dalam jangka waktu lama. Ada beberapa sarana yang dapat dipakai untuk mengurangi keluhan nyeri pada low back pain. Salah satu sarana itu adalah penggunaan korset untuk daerah lumbal (korset lumbal) dan melakukan back exercise berupa latihan penguatan otot-otot punggung bagian bawah. Penelitian dilakukan untuk pasien-pasien yang terdiri dari ibu-ibu rumah tangga yang mempunyai anak balita dengan kasus tersebut, di Klinik Fisioterapi Fitasoma Karanganyar Surakarta, dalam kurun waktu antara Januari sampai dengan Desember 2014. Penelitian ini merupakan penelitian eksperimen kuasi. Pengumpulan data dilakukan dengan cara observasi, wawancara, pemeriksaan fisik, dan dokumentasi. Melalui observasi dicari 40 responden, untuk selanjutnya dijadikan subyek penelitian. Berdasarkan hasil penelitian, ditemukan bahwa terjadi penurunan rasa nyeri pada dua minggu pertama, baik pada kelompok pemberian korset lumbal maupun kelompok pemberian back exercise. Selain itu, juga ditemukan perbaikan fungsional pada 
kelompok pemberian korset lumbal setelah minggu pertama, dan pada kelompok pemberian back exercise setelah minggu kedua.

Kata Kunci: Nyeri Low Back Pain, Korset Lumbal, Back Exercise

\section{PENDAHULUAN}

Nyeri Low Back Pain adalah sindroma nyeri yang terjadi pada daerah punggung bawah dengan penyebab sangat bervariasi. Penyebab itu antara lain peradangan, infeksi, degeneratif, metabolik, neoplasma, viserogenik, vaskuler, musculo sceletal, psikogenik, termasuk pula congenital dan traumatik serta pasca operasi (Sinaki, 1996). Penyebab mayoritas problem nyeri low back pain dalam masyarakat adalah faktor mekanik yang merugikan tulang punggung bawah, dalam keadaan posisi tegak (statis) maupun dalam keadaan berfungsi selama pergerakan aktif (Rosee, 1985).

Pada para ibu dengan anak balita yang masih membutuhkan digendong, nyeri low back pain mayoritas disebabkan faktor biomekanik, dengan istilah mechanical low back pain (low back pain non specific). Dalam kasus ini terjadi sprain pada tendon, ligamen, fascia, dan otot, serta terjadinya postur yang abnormal (Sinaki, 1996). Nyeri adalah mayoritas masalah yang ditemukan dalam kasus low back pain, yang dirasakan sangat mengganggu aktivitas dalam pekerjaan sehari-hari. Banyak upaya penanggulangan dan penatalaksanaan terapi yang telah dikaji namun hasil yang didapatkan belum mencapai optimal.

Kejadian nyeri low back pain, yang paling banyak dijumpai merupakan akibat dari kelainan mekanika gerak atau kelainan postural, yang berlangsung dalam jangka waktu lama (Brown, 1999). Beberapa ahli ergonomik menyatakan bahwa nyeri low back pain adalah suatu case work related musculo sceletal disorders, yang bersifat multi kompleks dengan efek multi kausal, dapat menyerang semua orang, usia, jenis kelamin, ras, status pendidikan, dan profesi (Hasyim, 2000).

Penelitian spesifik tentang nyeri low back pain, di Indonesia belum ada laporan secara riil. Namun, berdasarkan observasi peneliti di Klinik Fisioterapi maupun di Rumah Sakit Ortopedi (RSO) Prof. dr. Soeharso Surakarta, setiap hari rata-rata terdapat 6-8 pasien nyeri low back pain dari jumlah rata-rata pasien 6080 pasien yang hadir setiap hari. Dalam hal ini, riwayat pekerjaan adalah karyawan/ wati perusahaan dan dalam usia produktif. Penelitian serupa, pernah dilakukan di Klinik Fisioterapi Cempaka Medika, Jajar, Karangasem, Surakarta; dalam kurun waktu antara Januari sampai dengan Oktober 2007, terhadap para pekerja industri.

Dari sekian banyak cara, salah satu cara untuk mengurangi keluhan nyeri pada kondisi yang berkaitan dengan keluhan nyeri low back pain, adalah dengan pelaksanaan pemberian korset lumbal dan edukasi tentang back exercise. Dalam hal ini, pemakaian korset lumbal dapat memberikan perlindungan terhadap kemungkinan cidera (Pope, 1999); sedangkan pemberian back exercise sangat efektif untuk mencegah dan mengurangi nyeri low back pain akibat kerja, namun harus dilaksanakan dengan baik dan benar dalam bentuk home program (Brown, 1999). 
Sehubungan dengan hal itu, perlu dilakukan uji perbandingan pengaruh antara pemberian korset lumbal dan pemberian back exercise, untuk mengurangi keluhan nyeri low back pain non specific. Penelitian ini bertujuan untuk mengetahui adanya perbaikan atau pengurangan nyeri pada low back pain non specific, yang dibandingkan antara hasil pemberian korset lumbal dan back exercise, yaitu (1) untuk mengetahui pengaruh pemberian korset lumbal dibandingkan pengaruh pemberian back exercise, dan (2) untuk mengetahui perbaikan klinis dan perbaikan fungsional pada pasien nyeri low back pain non specific.

\section{METODE PENELITIAN}

Penelitian ini eksperimen kuasi dengan desain penelitian:

$\mathrm{R}$ - $\mathrm{O} 1$ - X1 ---- O2(X1) ---- $\mathrm{O} 3(\mathrm{X} 1) \rightarrow$

Kelompok low back pain dengan korset lumbal

$\mathrm{R}$ - $\mathrm{O} 1$ - X2 ---- O2(X2) ---- O3(X2) $\rightarrow$

Kelompok low back pain dengan back exercise

Keterangan:

$\mathrm{R}$ : Rancangan

O1 : Observasi low back pain sebelum perlakuan menggunakan korset lumbal maupun pemberian back exercise

X1 : Perlakuan low back pain dengan korset lumbal

X2 : Perlakuan low back pain dengan back exercise

O2(X1): Observasi low back pain setelah perlakuan menggunakan korset lumbal dengan jangka waktu 2 minggu pertama

O3(X1): Observasi low back pain setelah perlakuan menggunakan korset lumbal dengan jangka waktu 2 minggu kedua

O2(X2): Observasi low back pain setelah perlakuan pemberian back exercise dengan jangka waktu 2 minggu pertama

O3(X2): Observasi low back pain setelah perlakuan pemberian back exercise dengan jangka waktu 2 minggu kedua

Penelitian ini dilakukan di Klinik Fisioterapi Fitasoma, Tohudan, Colomadu, Karanganyar, Surakarta; pada periode Januari sampai dengan Desember 2014. Populasi penelitian ini adalah semua pasien dengan status ibu rumah tangga yang mempunyai anak balita, dengan keluhan low back pain non specific. Pasien yang terpilih diwajibkan memenuhi kriteria inklusi. Variabel bebas dalam penelitian ini adalah penggunaan korset lumbal dan latihan gerak statik otot-otot stabilisator lumbal. Variabel terikatnya adalah nyeri low back pain. Variabel kontrolnya adalah usia, berat badan, pendidikan, kelainan postur, dan kelainan jantung.

Peralatan yang dipakai dalam penelitian ini adalah (1) formulir isian, (2) stop watch, (3) timbangan berat badan, (4) meteran (mid line), (5) korset lumbal, (6) modul back exercise. Kemampuan yang diukur adalah (1) nyeri, (2) lingkup gerak sendi, (3) kecepatan gerak.

Pelaksanaan penelitian mengikuti tahapan (1) menetapkan pasien low back pain sesuai diagnosis dokter, (2) menetapkan kelompok pasien low back pain yang menggunakan korset lumbal dan pasien yang diberi back exercise, secara acak, yang memenuhi kriteria inklusi, (3) melakukan penilaian skala nyeri awal sebelum pemberian perlakuan, 
(4) pemberian korset lumbal selama 8 jam setiap hari kerja, dan pemberian back exercise pada saat istirahat sebelum dan sesudah beraktifitas, dengan dosis latihan selama 15 menit, ke dua kelompok mendapatkan informasi atau instruksi pemeliharaan dan proteksi punggung selama di rumah, (5) pengukuran dan penilaian skala nyeri setelah perlakuan selama satu bulan, (6) analisis data, (7) pengambilan kesimpulan. Pengumpulan data dilakukan di Klinik Fisioterapi Fitasoma tersebut, dengan menggunakan observasi, wawancara, dokumentasi, dan pemeriksaan fisik.

\section{HASIL PENELITIAN}

Hasil observasi menunjukkan 40 pasien low back pain non specific yang memenuhi persyaratan, ditetapkan sebagai subyek penelitian. Jumlah 40 pasien tersebut dibagi menjadi dua kelompok, masing-masing 20 pasien untuk kelompok perlakuan dengan korset lumbal dan 20 pasien untuk kelompok perlakuan dengan back exercise. Menurut sebaran hasil penelitian dalam usia, subyek penelitian berusia 31-35 tahun menunjukkan persentase tertinggi sebagai pasien low back pain non specific $(42,5 \%)$, berusia 26-30 tahun (37,5\%), berusia 21--25 tahun $(20 \%)$. Keadaan ini sesuai dengan pendapat La don J. (1990) bahwa semakin tua usia, pada usia 36-40 tahun terjadi penurunan fungsi tubuh, sehingga resiko untuk terkena low back pain lebih besar. Menurut penelitian Kaplan dan Tanner (1989), persentase low back pain tertinggi adalah pada usia 40 tahun ke atas. Menurut Toha Muslim (1994), low back pain mulai dirasakan pada usia $20-40$ tahun, yang diperkirakan oleh faktor degenerasi dan beban statik terus menerus serta osteoporosis.
Tingkat pendidikan pada sebaran penelitian ini adalah perguruan tinggi (58\%) merupakan peringkat tertinggi, dan lama keluhan tertinggi adalah 1-6 bulan. Keadaan ini menunjukkan bahwa pendidikan tinggi tidak signifikan dalam hal disiplin ergonomik. Uji antar pengamatan dalam kelompok korset lumbal maupun kelompok back exercise dilakukan hanya untuk pengamatan perubahan rasa nyeri pada masing-masing periode. Uji beda antar pengamatan dalam kelompok korset lumbal, antara $\mathrm{O}$ (observasi) dan X1 (dua minggu I) diperoleh $\mathrm{z}=3.601$ dengan $p=0.000$. Antara X1 (dua minggu) dengan X2 (dua minggu II) diperoleh $\mathrm{z}=1.52$ dan $p=$ $0.234(p>0.05)$. Hal ini menunjukkan bahwa terjadi penurunan keluhan nyeri yang sangat bermakna setelah dua minggu pertama. Tetapi setelah periode dua minggu kedua, tidak terjadi penurunan nyeri yang bermakna, sehingga dapat disimpulkan bahwa penurunan keluhan nyeri hanya terjadi pada pemakaian korset lumbal dua minggu pertama, sedangkan pada dua minggu berikutnya tidak terjadi penurunan keluhan nyeri yang berarti. Temuan ini sejalan dengan pendapat Borenstein (1995) yang menyatakan bahwa penggunaan korset lumbal akan memberikan stabilisasi pasif pada vertebra, sehingga membatasi gerakan yang menimbulkan nyeri muskular. Pemakaian korset lumbal kurang efektif apabila lebih dari dua minggu, karena dapat mengakibatkan penurunan kekuatan (Calliet, 1981).

Uji beda antara pengamatan dalam kelompok back exercise antar $\mathrm{O}$ dan setelah X1 (setelah dua minggu) diperoleh nilai $\mathrm{z}=-3.00$ dan $p=0.003(p<0.05)$. Hal ini menunjukkan ada penurunan rasa nyeri yang bermakna. Hal ini sama juga 
terjadi pada pengamatan X2 (setelah dua minggu II) dengan $\mathrm{z}=-2.663$ dan $p=$ $0.0007(p<0.05)$ yaitu terjadi penurunan nyeri yang bermakna. Pada kelompok yang melakukan back exercise terjadi penurunan rasa nyeri yang terus menerus pada setiap periode perlakuan.

Uji beda nyeri saat observasi kelompok korset lumbal dan kelompok back exercise diperoleh nilai MannWhitney $(\mu)=200.0$ dan $p=1.00$. Dalam hal ini karena nilai $p<0.05$ maka secara statistik tidak ada perbedaan yang bermakna atau homogen. Jadi, saat observasi, nilai keluhan nyeri kelompok korset lumbal dan kelompok back exercise adalah sama. Keadaan ini menunjukkan bahwa kelompok subyek penelitian adalah homogen sesuai dengan kriteria inklusi yang belum diintervensi, yaitu belum mendapatkan perlakuan dengan korset lumbal maupun back exercise.

Uji beda lingkup gerak sendi pada saat observasi antara kelompok korset lumbal dan kelompok back exercise, diperoleh nilai $\mu=82.0$ dengan $p=0.001$ $(p<0.05)$.Hal ini menunjukkan ada perbedaan yang bermakna antara kedua kelompok. Kelompok korset lumbal dengan $\mu=14.50$ lebih kecil daripada kelompok back exercise dengan $\mu=$ 26.10, sehingga secara statistik tidak homogen, nilai lingkup gerak sendi kelompok korset lumbal lebih rendah bila dibandingkan dengan lingkup gerak sendi kelompok back exercise. Keadaan ini menunjukkan bahwa kelompok subyek penelitian tidak homogen karena keterbatasan subyek penelitian.

Uji beda kecepatan gerak pada saat observasi antara kelompok korset lumbal dan kelompok back exercise diperoleh nilai $\mu=180.0$ dengan $p=0.601(p>$ $0.05)$, sehingga secara statistik tidak ada perbedan bermakna (homogen). Keadaan ini menunjukkan bahwa kelompok subyek penelitian homogen, sesuai dengan kriteria inklusi yang belum diintervensi atau diberi perlakuan, baik dengan korset lumbal mapun back exercise.

Uji beda nyeri setelah dua minggu pertama antara kelompok korset lumbal dan kelompok back exercise diperoleh nilai Mann-Whitney $(\mu)=160.0$ dan $p=$ $0.279(p>0.05)$. Dalam hal ini secara statistik tidak ada perbedaan yang bermakna pada nilai nyeri antara kelompok korset lumbal dan kelompok back exercise. Kejadian ini menunjukkan bahwa antara kelompok korset lumbal dan kelompok back exercise terjadi penurunan nyeri yang sama besar. Sesuai dengan hasil penelitian Marras (2000) bahwa penggunaan korset lumbal pada low back pain selama dua minggu akan memperbaiki stabilisasi lumbal, terutama dari pengaruh pembebanan dan gerakan fleksi bidang sagital.

Uji beda lingkup gerak sendi setelah dua minggu pertama antara kelompok korset lumbal dan kelompok back exercise, diperoleh nilai $\mu=195.0$ dengan $p=0.901(p>0.005)$, secara statistik tidak ada beda antara kelompok yang menggunakan korset lumbal dan kelompok yang melakukan back exercise, setelah dua minggu pertama perlakuan. Secara teori, lingkup gerak sendi dapat dipengaruhi oleh rasa nyeri (Felix, 1990). Salah satu faktor yang ikut menentukan lingkup gerak sendi adalah tonus otot dalam keadaan rileks atau tidak, sehingga mempengaruhi mobilitasnya, meningkat atau tidak. Pemakaian korset lumbal dan back exercise dapat memberikan efek rileksasi pada otot-otot punggung (Calliet, 1981). 
Uji beda kecepatan gerak setelah dua minggu pertama antara kelompok korset lumbal dan kelompok back exercise diperoleh nilai $\mu=200.0$ dengan $p=1.00$ $(p>0.05)$, sehingga secara statistik tidak ada perbedaan antara kedua perlakuan tersebut setelah dua minggu pertama. Sesuai dengan pendapat Parjoto (2000) bahwa kecepatan gerak membungkuk pada pasien low back pain sangat tergantung derajat nyeri. Semakin nyeri maka kecepatan gerak ini semakin lambat (Parjoto, 2002).

Uji beda nyeri setelah dua minggu kedua antara kelompok korset lumbal dan kelompok back exercise, diperoleh nilai Mann-Whitney $(\mu)=122.0$ dan $p=0.036$ $(p<0.05)$. Dengan demikian secara statistik ada perbedaan yang bermakna pada nilai nyeri, antara kelompok korset lumbal dan kelompok back exercise dalam dua minggu kedua. Kelompok korset lumbal dengan mean rank $=24.31$ lebih besar daripada kelompok back exercise dengan mean rank $=16.61$. Dalam hal ini dapat dijelaskan bahwa setelah periode dua minggu kedua, kelompok korset lumbal semakin nyeri bila dibandingkan dengan kelompok back exercise. Hal ini sesuai dengan pendapat Borenstein (1995), yang menyatakan bahwa pemakaian korset lumbal lebih dari jangka waktu dua minggu secara terus menerus tanpa diikuti back exercise, akan potensial menimbulkan atrofi otot, sehingga otot menjadi lemah dan mudah mengalami cidera. Sesuai dengan hasil penelitian Widodo (1996), yang mengutarakan bahwa exercise dapat meningkatkan kekuatan otot-otot perut dan punggung sehingga keadaannya lebih stabil.

Uji beda lingkup gerak sendi setelah dua minggu kedua antara kelompok korset lumbal dan kelompok back exercise diperoleh nilai $\mu=109.0$ dengan $p=0.011(p<0.05)$. Secara statistik ada perbedaan yang bermakna, antara kelompok yang menggunakan korset lumbal dan kelompok yang melakukan back exercise, setelah dua minggu kedua perlakuan. Secara statistik dapat dijelaskan bahwa nilai lingkup gerak sendi kelompok korset lumbal lebih kecil dibandingkan dengan nilai lingkup gerak sendi kelompok back exercise. Lingkup gerak sendi pada kelompok back exercise lebih baik dibandingkan dengan kelompok lumbal corset. Menurut Kisner (1990), back exercise yang dilaksanakan secara baik dan benar, mempunyai efek mengurangi nyeri, menambah lingkup gerak sendi, dan meningkatkan mobilitas gerak atau kecepatan gerak.

Uji beda kecepatan gerak setelah dua minggu kedua antara kelompok korset lumbal dan kelompok back exercise diperoleh nilai $\mu=170.0$ dengan $p=$ $0.427(p>0.05)$, sehingga secara statistik tidak ada perbedaan antara kedua perlakuan tersebut setelah dua minggu kedua. Tetapi berdasarkan mean rank, terlihat bahwa mean rank kecepatan gerak kelompok korset lumbal adalah 18.00 dan kelompok back exercise adalah 21.00. Keadaan ini menunjukkan bahwa ada perbedaan, kecepatan gerak pada kelompok back exercise lebih baik dibandingkan dengan kelompok korset lumbal. Jadi, dapat disimpulkan bahwa perubahan kecepatan gerak untuk kelompok back exercise lebih baik bila dibandingkan dengan kelompok korset lumbal.

\section{KESIMPULAN DAN SARAN}

Kesimpulan dari penelitian ini adalah (1) Pengurangan rasa nyeri, baik pada kelompok korset lumbal maupun 
kelompok back exercise, terjadi setelah dua minggu pertama perlakuan. Namun, perbaikan atau peningkatan LGS dan kecepatan gerak hanya terjadi pada kelompok back exercise. Hasil pengamatan setelah dua minggu ke dua menunjukkan, bahwa ada pengurangan rasa nyeri, peningkatan lingkup gerak sendi, dan kecepatan gerak. Hasil ini didapat hanya pada kelompok back exercise. (2) Penelitian ini menunjukkan pula bahwa perbaikan fungsional terjadi setelah dua minggu pertama untuk kelompok korset lumbal, karena penurunan keluhan low back pain lebih nyata dirasakan pada kelompok korset lumbal. Pada kelompok back exercise, perbaikan fungsional diperoleh setelah minggu ke dua, karena keluhan low back pain lebih baik dibandingkan kelompok korset lumbal.

Hasil dari penelitian ini mirip dengan hasil dari penelitian serupa, yang pernah dilakukan di Klinik Fisioterapi Cempaka Medika, Jajar, Karangasem, Surakarta; dalam kurun waktu antara Januari sampai dengan Oktober 2007, terhadap para pekerja industri.

Saran yang bermanfaat untuk pengembangan penelitian dan pelayanan kesehatan adalah (1) Pengurangan keluhan nyeri low back pain dapat dilakukan dengan penggunaan korset lumbal dalam jangka waktu pendek sebelum dua minggu. Apabila pasien kembali mengeluh nyeri low back pain maka korset lumbal dapat dipakai lagi. (2) Pemberian motivasi kepada pasien penting untuk dilakukan, agar menyadari perlunya melakukan back exercise rutin setiap hari, sebelum dan sesudah melakukan aktivitas sehari-hari, untuk mencegah dan mengurangi nyeri low back pain. (3) Untuk mendapatkan hasil penelitian yang jauh lebih baik; diharapkan dapat dilakukan penelitian lebih lanjut dengan jangka waktu lebih lama, sampel penelitian lebih besar dan homogen, serta untuk mendapatkan hasil penelitian yang jauh lebih baik. (4) Perlu adanya pemberian edukasi kepada pasien, agar mereka melakukan proteksi terhadap keluhan nyeri low back pain dengan memakai korset lumbal apabila merasakan ada keluhan nyeri low back pain. Apabila keluhan nyeri low back pain dirasakan lebih dari dua minggu maka dianjurkan untuk melakukan back exercise.

\section{DAFTAR RUJUKAN}

Brown A. and Makckler L. S., 1999; Diagnosis of Medical Low Back Pain in a Labore; journal of Orthopaedic \& Sport Physical Therapy, Vol. 29 (9), American PT.

Hasyim H., 2000; Low Back pain pada Operator Komputer; Temu Ilmiah Tahunan Fisioterapi (Titafi) ke XV, Semarang.

Kisner, Carolyn, 1990; Therapeutic Exercise Foundation and Techniques; Philadhelpia, F. A. Davis Company.

La don J., 1990; Occupational Medicine; California, Appleton and lange.

Parjoto, Slamet, 2000; Pengukuran Kecepatan Gerak Motorik pada Penderita LBP; Temu Ilmiah tahunan Fisioterapi (Titafi) ke XV, Semarang.

Sinaki, M., Mokri, B., 1996; Low Back pain and Disorder of the Lumbar Spine in: Braddon R.I., Ed, Physical Medicine and Rehabilitation, Philadhelpia, W. B. Saunders Company. 